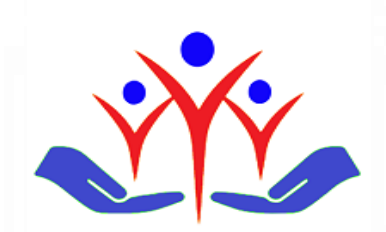

ISSN 2458-8865

\title{
Chilaiditi syndrome in a child with cerebral palsy presenting with recurrent abdominal pain
}

Tekrarlayan karın ağrısı ile başvuran serebral palsili bir çocukta chilaiditi sendromu

\author{
(D) Fatma Dilsad Aksoy ${ }^{\mathrm{a}}$, Esra Ture ${ }^{\mathrm{b}}$, ADnur Karaca $^{\mathrm{a}}$, Seda Sinem Yurdaor $^{\mathrm{c}}$ \\ a Department of Pediatrics, Bursa City Hospital, Bursa, Turkey \\ b Department of Pediatric Emergency, Bursa City Hospital, Bursa, Turkey \\ c Department of Emergency, Bursa City Hospital, Bursa, Turkey
}

\begin{abstract}
Introduction: The hepatodiafragmatic interposition of colon is called Chilaiditi sign. For symptomatic patients, the term "Chilaiditi syndrome" is used, this term was first reported in 1911 by Demetrius Chilaiditi, a Viennese radiologist, in three asymptomatic patients. Patients are commonly asymptomatic, and some patients may apply with gastrointestinal or respiratory symptoms such as abdominal pain or chest pain. In the study of Lekkas et al, the incidence of Chilaiditi syndrome in mental retarded patients was reported to be 63 times higher than normal population.

Case Presentation: High liver dome and elevated right diaphragm, hepatic flexura replaced between liver and anterior wall of abdomen were observed in chest radiography and abdominal computer tomography of our 6,5 year old male patient with cerebral palsy who has mental retardation and recurrent abdominal pain in medical history.

Conclusions: In conclusion, Chilaiditi syndrome should be considered in mental retarded children with recurrent abdominal pain.

Keywords: Child, chilaiditi syndrome, recurrent abdominal pain, mental retardation, cerebral palsy
\end{abstract}

\section{ÖZ}

Giriş: Kolonun hepatodiafragmatik interpozisyonuna Chilaiditi işareti denir. Semptomatik hastalar için "Chilaiditi sendromu" terimi kullanılır, bu terim ilk olarak 1911'de Viyanalı bir radyolog olan Demetrius Chilaiditi tarafından üç asemptomatik hastada bildirilmiştir. Hastalar genellikle asemptomatiktir ve bazı hastalar karın ağrısı veya göğüs ağrısı gibi gastrointestinal veya solunum semptomları ile başvurabilir. Lekkas ve arkadaşlarının çalışmasında zihinsel engelli hastalarda Chilaiditi sendromu görülme sıklı̆̆ının normal popülasyondan 63 kat daha fazla olduğu bildirilmiştir.

Vaka Sunumu: Tıbbi öyküsünde zeka geriliği ve tekrarlayan karın ağrısı olan 6,5 yaşındaki erkek hastamızın akciğer grafisinde ve abdominal bilgisayar tomografisinde yüksek karaciğer kubbesi ve yüksek sağ diyafram, karaciğer ile karın ön duvarı arasında yer alan hepatik fleksura izlendi.

Sonuç: Sonuç olarak Chilaiditi sendromu, tekrarlayan karın ağrısı olan zihinsel engelli çocuklarda düşünülmelidir.

Anahtar kelimeler: Çocuk, chilaiditi sendromu, tekrarlayan karın ağrısı, zeka geriliği, serebral palsi

\begin{tabular}{|c|c|c|c|c|}
\hline Received & Accepted & Published Online & Corresponding Author & E-mail \\
\hline February 5, 2021 & September 10, 2021 & September 16, 2021 & Fatma Dilsad Aksoy, MD & fatmadilsad@uludag.edu.tr \\
\hline Correspondence & \multicolumn{4}{|l}{ Dr. Fatma Dilşad Aksoy, Department of Pediatrics, Bursa City Hospital, 16110, Bursa, Turkey } \\
\hline
\end{tabular}




\section{Introduction}

Colonic interposition is temporary or permanent replacement of a segment of large intestine between two organs, unlike its ordinary anatomical location. The possible locations of colon are between the liver and diaphragm, spleen and diaphragm, spleen and left kidney, or stomach and pancreas. The hepatodiafragmatic interposition of the large intestine is called the Chilaiditi sign, while the other interpositions are called the nonchilaiditi sign [1]. Hepatodiaphragmatic interposition is a rare condition observed in the general population at the rate of $0.02-0.08 \%$. It is four times more common in men than women [2]. It was first reported by Demetrius Chilaiditi, a Viennese radiologist in 1911, in three asymptomatic patients [3]. The terminology of "Chilaiditi sign" is used for asymptomatic patients and "Chilaiditi syndrome" is used for symptomatic patients $[2,4]$. Patients are commonly asymptomatic, some patients may develop gastrointestinal or respiratory symptoms such as abdominal pain or chest pain. It is also important this anatomic variant to be considered in diagnose by clinicians because it can be confused with severe clinical conditions such as pneumoperitoneum and diaphragm hernia [5]. In this article, Chilaiditi syndrome and its relation with motor-mental retardation were discussed based on a patient who applied to our pediatric emergency department with abdominal pain.

\section{Case Presentation}

A 6.5-year-old male patient was brought to the emergency room with the complaint of restlessness abdominal pain lasting for two days, multiple episodes of constipation and abdominal pain attacks over a year. The patient had neuromotor retardation since birth and was being followed by pediatric neurology due to the corpus callosum agenesis. The patient walked at the age of 4.5 , can walk without support but unbalanced, use 2-3 words while talking, unable to form a sentence. The patient, who is fed with a nasogastric catheter until the age of 3.5, is currently being fed by spoon by his mother. In physical examination; the patient was conscious, restless, agitated, with limited eye contact. His respiration rate: 22 / min, lungs sound bilateral equal, no ral roncus, bowel sounds were heard in the right basal hemithorax. The liver was palpated $1 \mathrm{~cm}$ under the ribs. Physical examination revealed a rigid abdomen. Other system examinations were natural. The abdominal $\mathrm{x}$-ray showed free air under the diaphragm (Figure1). Contrast tomography of the lower abdomen was performed. On computed tomography (Figure 2), it was observed that the dome of the liver was located high, the right diaphragm was elevated, the hepatic flexure was displaced between the liver and the anterior wall of the abdomen. Patient was diagnosed as Chilaiditi syndrome with these findings. His hemogram and biochemical parameters were normal. The patient 's abdominal pain relieved after intervention with high enema. The patient and his familiy were adviced on rich dietary recommendations and discharged with laxative treatment.

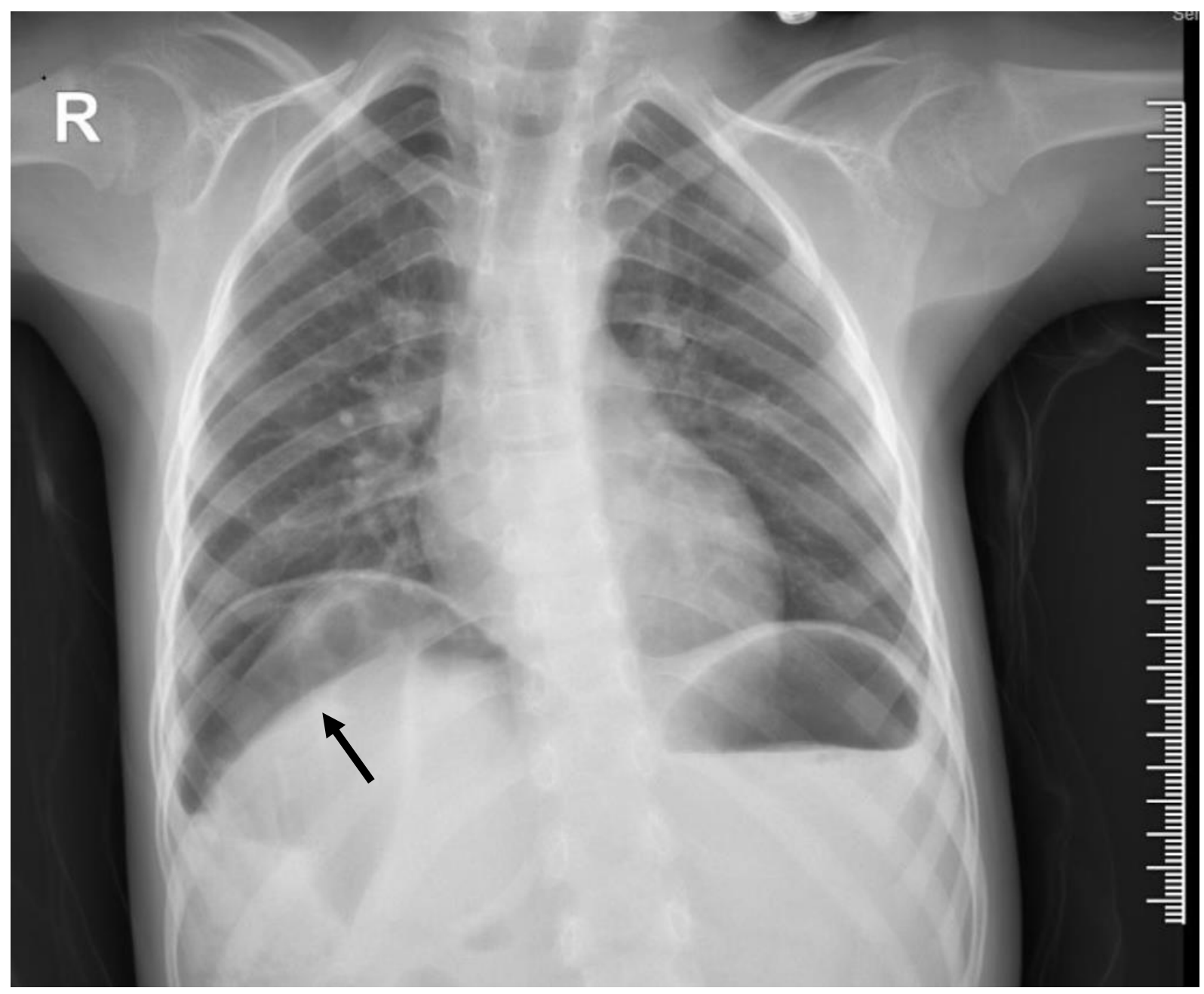

Figure 1. X-ray shows free air under the diaphragm (marked with arrow) 


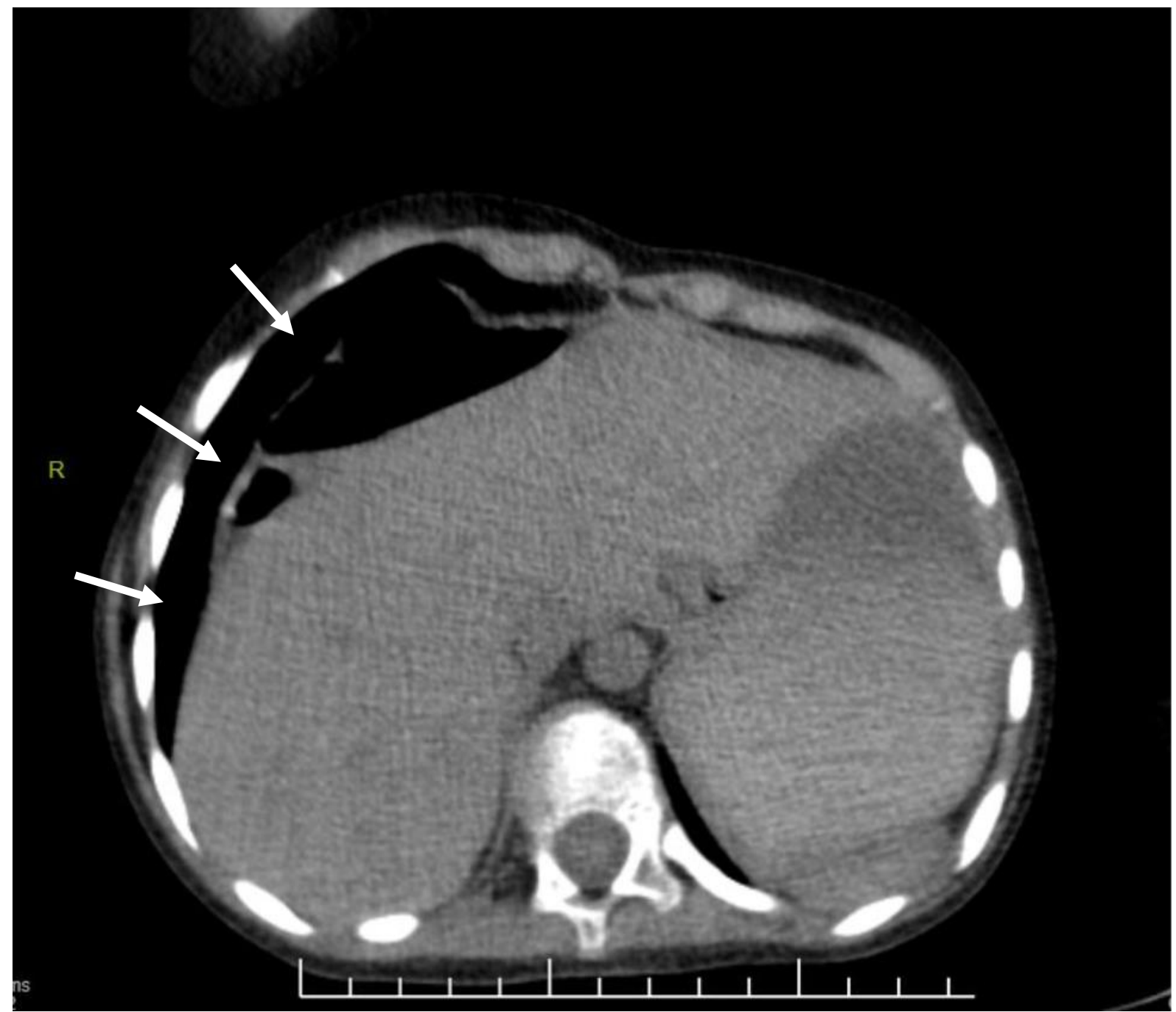

Figure 2. Computed tomography shows that the dome of the liver was located high, the right diaphragm was elevated, the hepatic flexure was displaced between the liver and the anterior wall of the abdomen (marked with arrows)

\section{Discussion}

In our case, there were findings of abdominal pain and constipation causing recurrent hospital admissions similar to the literature data. In the study of Lekkas et al. [7], Chilaiditi syndrome was observed in 12 of 135 mentally retarded patients with rate of $8.8 \%$ is 63 times higher than the normal population. In some of the 12 patients with Chilaiditi syndrome, aerophagia was observed due to fast eating and swallowing behavior. These patients tend to have hypotonic colons due to immobility [7]. Moreover, in this study, it was theoretically claimed that mental retardation itself can cause this syndrome by causing a defect in the parasympathetic-sympathetic nerve stimulation of the colon [7]. Matsuo et al. [8] blamed excessive air swallowing and associated abdominal distension as possible causes in three schizophrenic patients. Our patient also had corpus callosum agenesis and mental retardation, the patient could walk without support with an unsteady gait. His daily motor activity was less than normal, and spoon-feeding may also cause aerophagia in our patient. 3 criteria are sought for the radiological diagnosis. These are; the right hemidiaphragm pushed upwards over the liver due to malposition of bowel segments, the intestinal segment filled with air (pseudopneumoperitoneum), and the upper edge of the liver being visible lower than the left hemidiaphragm level [7]. The presence of these 3 findings in the contrast- abdominal tomography in our patient supported the diagnosis. Treatment is almost entirely conservative. Sufficient fluid intake, enemas, laxatives and fiber-rich diet are among suggestions. Patients and families should be informed about this clinical situation [2,6].

\section{Conclusion}

Early diagnosis of Chilaiditi syndrome which is a rare cause, in the differantial diagnosis while investigating the etiology of recurrent abdominal pain is important to minimize unnecessary surgical interventions such as laparotomy or endoscopic intervention, which may lead to potential complications such as perforation, intestinal wall ischemia or respiratory failure [9].

\section{Conflict of interest: None}

Financial support: None 


\begin{tabular}{|c|r|l|}
\hline \multicolumn{2}{|c|}{ Author Contributions } & Author Initials \\
\hline SCD & Study Conception and Design & FDA, ET \\
\hline AD & Acquisition of Data & AK, SSY \\
\hline AID & Analysis and Interpretation of Data & FDA, ET \\
\hline DM & Drafting of Manuscript & FDA, AK, SSY \\
\hline CR & Critical Revision & ET \\
\hline
\end{tabular}

\section{References}

1. Weng WH, Liu DR, Feng CC, Que RS. Colonic interposition between the liver and left diaphragm - management of Chilaiditi syndrome: A case report and literature review. Oncol Lett. 2014;7(5):1657-60. https://www.ncbi.nlm.nih.gov/pmc/articles/PMC3997735/

2. Haddad CJ, Lacle J. Chilaiditi's syndrome. A diagnostic challenge. Postgrad Med. 1991;89(4):249-52. https://doi.org/10.1080/00325481.1991.11700877

3. Chilaiditi D. Zur Frage der Hepatoptose und Ptose im allgemeinen im Anschluss an drei Falle von temporarer, partieller Leberverlagerung. Fortschr Rontgenstr 1910;16:173-207.

4. Fisher AA, Davis MW. An elderly man with chest pain, shortness of breath, and constipation. Postgrad Med J 2003;79(929):180-4. http://dx.doi.org/10.1136/pmj.79.929.180

5. Saber AA, Boros MJ. Chilaiditi's syndrome: what should every surgeon know? Am Surg 2005;71(3):261-3. https://doi.org/10.1177/000313480507100318

6. Moaven O, Hodin RA. Chilaiditi syndrome: a rare entity with important differential diagnoses. Gastroenterol Hepatol (NY) 2012;8(4):2768. https://pubmed.ncbi.nlm.nih.gov/22723763/

7. Lekkas CN, Lentino W. Symptom-producing interposition of the colon. Clinical syndrome in mentally deficient adults. JAMA 1978;240(8):747-50. https://www.ncbi.nlm.nih.gov/pubmed/671703

8. Matsuo T, Kotsubo D, Ichiki S, Tagawa K, Kitazono T, Nakao Y et al. Chilaiditi's syndrome in schizophrenic patients. Jpn J Psychiatry Neurol 1987;41(1):71-5. https://doi.org/10.1111/j.1440-1819.1987.tb00393.x

9. Kumar A, Mehta D. Chilaiditi Syndrome. [Updated 2021 Apr 20]. In: StatPearls [Internet]. Treasure Island (FL): StatPearls Publishing; 2021 Jan-. Available from: https://www.ncbi.nlm.nih.gov/books/NBK554565/ 